\title{
SOME COMPETITIVE PRACTICES WITH WHICH SMALL BUSINESS MUST CONTEND
}

\author{
Albert A. Carretta*
}

The Small Business Act, ${ }^{1}$ approved by the President on July 18, I958, defines a small business concern as "one which is independently owned and operated and which is not dominant in its field of operation." 2 This is a rather broad definition, but it appears adequate for purposes of the present paper. The Small Business Act also recites a statement of policy which should warm the hearts of those who fear the current trend to bigness. Included in this statement is the following language: ${ }^{3}$

It is the declared policy of the Congress that the Government should aid, counsel, assist, and protect, insofar as is possible, the interests of small-business concerns in order to preserve free competitive enterprise. ...

As of December 3I, I957, there were in existence in the United States 4,322,700 business firms, excepting those engaged in professional services and agriculture. ${ }^{4}$ The breakdown of these firms was this:

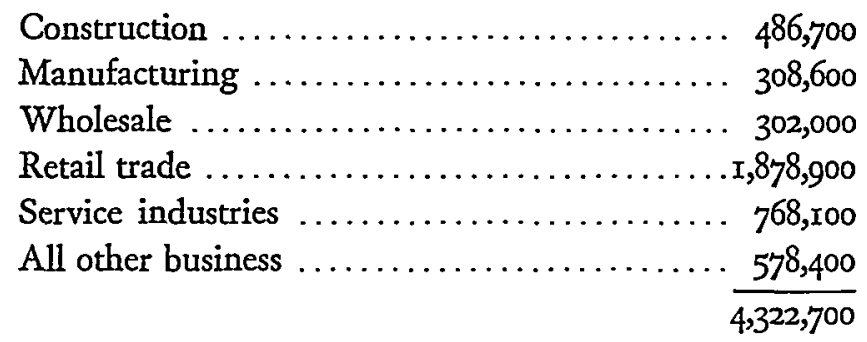

Of all these business concerns, almost forty-four per cent were engaged in the retail trade. Consequently, it can reasonably be assumed that any competitive practice which affects the retail trade also affects a substantial percentage of the total business firms in the United States (excepting, again, those engaged in professional services and agriculture).

If the retailers were asked to name their most pressing business problem today, their general answer would be "discount houses." For about a quarter of a century, there has been a slow but continuous growth in the number of retail outlets which have attracted the consumers' dollars through use of the word "discount." Although the practice of price-cutting employed by such outlets is by no means new, the

* B.S. 1930, College of the City of New York; LL.B. I940, Georgetown University. Member of the District of Columbia and Virginia bars. Member of the Federal Trade Commission, 1952-54.

${ }^{1} 72$ StAT. 384 (1958), I5 U.S.C.A. $\$ \$ 63$ I et seq. (Supp. 1959).

Id. $\$ 632$.

${ }^{3} I d . \$ 63 \mathrm{I}(\mathrm{a})$.

${ }^{4}$ Survey of Current Business, Aug. I958, p. 4. 
apparent recent growth in sales made by discount houses is beginning to cause their competitors to "sit up and take notice." Yet, obviously, this concern with the problem of discount houses will not, without further action, increase the number of sales recorded on the cash registers of the millions of independent retailers throughout the United States.

Too many Americans, both in the ranks of management and of distribution, make the error of looking upon the present period of intense and sometimes unscrupulous competition as being only a temporary condition. They plan to wait patiently until the "temporary condition" has righted itself. However, the adoption of such a plan by independent retailers plagued with the competition of discount houses can only lead to business failures.

To discuss this special problem that faces the retail distributors, it will be necessary to define certain terms so as properly to limit the application of the conclusions reached.

"Retailers" generally are considered to be merchants who buy articles in large quantities and who sell such articles in small quantities, usually to ultimate consumers. But since such a definition would include discount houses, it will have to be qualified. As used herein, "retailers" are only those merchants who do business in the so-called "fair trade" states, and who buy articles in large quantities and sell such articles in small quantities at or above the stipulated or minimum prices set by the manufacturers in fair trade agreements. Such a definition, of course, excludes discount houses. For convenience, those falling within this definition will also sometimes be referred to as "conventional retailers" or "ethical retailers."

"Fair trade" is more often than not misunderstood. As used herein, the term "fair trade" shall refer to the method of merchandising originally legalized by the statutes enacted in forty-five states of the United States, commonly referred to as fair trade statutes. The Miller-Tydings Act of $1937^{6}$ and the McGuire Act of $1952^{7}$ exempted fair trade contracts from the prohibitions of the Sherman Antitrust $\mathrm{Act}^{8}$ and the Federal Trade Commission Act. ${ }^{9}$

These state laws generally permit, but they do not compel, a manufacturer of certain goods identified by a trade-mark, brand, or name to guard the property value of such trade-mark, brand, or name by permitting him to set the minimum prices at which such products may be resold. They generally provide that the minimum resale price provision of fair trade contracts shall be binding not only upon all distributors who sign such contracts, but also upon all other distributors of the same products who have knowledge of the existence of a fair trade contract between a manufacturer and a distributor covering the same products identified by a trademark, brand, or name. No retailer or distributor is required to carry and offer for

\footnotetext{
${ }^{5}$ CCH Trade Reg. Rep. \3075 (Ioth ed. I956).

50 STat. 693, I5 U.S.C. $\$ 5$ I et seq. (1952).

${ }^{7} 66$ STAT. 632, I5 U.S.C. $\$ \$ 45$ et seq. (I952).

${ }_{2} 26$ STAT. 209 (1890), I5 U.S.C. \$\$ I-7 (1952).

${ }^{8} 38$ STAT. 7I7 (I9I4), I5 U.S.C. $\$ \$ 4$ I et seq. (1952).
} 
sale any fair-traded product. But if a retailer does, and he either enters into a fair trade contract with the manufacturer, or knows of the existence of such a contract, then he must respect the minimum resale price provision of such contract.

The state fair trade statutes should not be confused with any of the unfair practices acts adopted by many of the states; or with any of the state anti-price discrimination acts; or with the Robinson-Patman Act; ${ }^{10}$ or with any other antitrust legislation of either the federal government or of the state governments.

"Discount houses" could very simply be defined as "price-cutters." But not all price-cutters are intended to be covered herein. "Discount houses" have been defined as retail distributors who sell merchandise at a discount from the manufacturer's listed retail price or from the price at which other types of retailers sell the same merchandise. This definition, however, is too broad for the purposes of this article. Because of the current controversy over the economic wisdom of fair trade statutes, the term "discount houses" as used herein shall apply only to those retail distributors located in a fair trade state who sell articles at prices below the minimum resale prices legally fixed by the manufacturers thereof in a fair trade agreement of which the retail distributors have knowledge. It can readily be seen that this definition excludes the ordinary price-cutters, who have no obligation to maintain prices. This definition also excludes those retail distributors who cut price on articles which are not fair-traded by the manufacturers, but which carry only "suggested" resale prices.

The consuming public has been told over and over again that fair trade means fixed prices at high levels. Many consumers have believed this assertion because at the same time it was being made by discount house operators, these same operators were offering the public fair-traded items at less than the minimum resale prices fixed by the manufacturers of those items. Why then did at least a majority of the legislatures of forty-five states vote for fairly uniform state fair trade statutes? Why then did approximately ninety-one per cent of the congressmen voting at the time favor the enactment of the McGuire Act?

\section{Purposes of Fair Trade Legislation}

Remembering the old maxim that "there is a little bit of good in every bad little boy," let us examine a typical fair trade law to determine if it has any good points. First and foremost, these statutes generally provide that resale price maintenance agreements may be entered into only with respect to commodities which bear the trade-mark, brand, or name of the producer of such commodity. Thus, resale price maintenance agreements would seem illegal when entered into with respect to any commodity which does not bear the trade-mark, brand, or name of its producer. Obviously, the aim of the statutes was to protect the property-namely, the good will-of the producer; and the price restriction provision was adopted as an appropri-

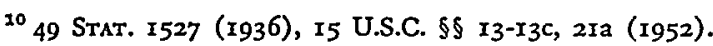


ate means to that perfectly legitimate end, and not as an end in itself. Such was the opinion of a unanimous Supreme Court in December $1936 .{ }^{11}$

Quite frequently, because of the quality of his product or the waging of an extensive advertising campaign, a manufacturer's trade-name become valuable to recailers who distribute his product. Even when the product of other manufacturers is almost equally good, the trade name may assure to the retailer a ready market for the product. Now, if the manufacturer sold his product directly to the ultimate consumer, there would be no question of his right and ability to control the price at which the product would reach the public. If, however, instead of selling directly to the ultimate user, the manufacturer decided, perhaps long ago, to use retail outlets as his distributors, the situation is somewhat different.

Undeniably, when a retail outlet purchases the product, title thereto passes to the retailer. But the retail distributor is dealing not with a commodity alone, but with a commodity plus the brand-name which it carries as evidence of its origin and the quality for which the brand-name stands. Despite the ownership he may acquire of the product, the retailer cannot acquire ownership of the trade-name or the good will which it symbolizes. As the Supreme Court has put it:12

The ownership of the good will, we repeat, remains unchanged, notwithstanding the commodity has been parted with.

If a retailer who desired to sell below the manufacturer's nationally advertised price were willing to remove the trade-name from the product and to neither state nor imply that they were the same as the nationally advertised goods, then the retailer would seem clearly entitled to sell at whatever price he pleased. However, discount houses are totally unwilling to market a popular product in this manner. And so they run afoul of the Supreme Court's pronouncement:13 "Ownership of the goods does not carry the right to sell them with a specific mark." The fair trade laws give effect to this view.

Fair trade laws generally provide that, to be the subject of a permissible resale price maintenance agreement, a commodity must be "in free and open competition with commodities of the same general class produced or distributed by others." This is a basic antimonopoly provision contained in state fair trade statutes, in the MillerTydings Act, and in the McGuire Act, and it is important because it prevents gouging of the consuming public and the fixing of fair trade prices at high levels. The prices of commodities sold in free and open competition with other commodities of the same general class will always be subject to the powerful forces of competitive bids and offers. If the manufacturer of a trade-marked product which is fairtraded should market his product at a price that the consumer deems too high, then the consumer will naturally purchase a commodity of the same general class which is produced by another manufacturer who does fair-trade his product at a

${ }^{11}$ Old Dearborn Distributing Co. v. Seagram Distillers Corp., 299 U.S. 183 (1936).

12 Id. at 195 .

${ }^{13}$ Bourjois \& Co. v. Katzel, 260 U.S. 689,692 (1923). 
lower price. Moreover, it should be remembered that a manufacturer establishes his fair trade price at his own peril-especially the peril that if he sets it too high, either the consumer will not buy the product or, should the article remain popular nonetheless, the high profits will invite even more competition from other manufacturers. If trade-marked products which are subject to resale price maintenance agreements actually are in free and open competition with commodities of the same general class produced by others, then in due course, any fixed resale prices with too much "fat" will eventually-as the natural result of competition-be reduced to a level that consumers are willing to pay. This circumstance is not generally understood, because the consuming public has been told repeatedly that fair trade means fixed prices at high levels.

As a further protection to the consumer, state fair trade laws and the McGuire Act do not countenance price-fixing agreements between or among competitorsthat is, competitors may not combine to fix prices. Only "vertical"-and not "horizontal"-agreements are permitted under the fair trade statutes.

The problem which confronts the ethical retailers of today is basically one of unscrupulous competition and discriminatory enforcement of fair trade agreements by manufacturers. Price-cutters of fair-traded items in the great majority of cases realize that their activities can be enjoined without too much difficulty by the institution of a suit either by the manufacturers of the products being sold at cut prices or by a competing retailer. But the price-cutters are willing to take the calculated risk because they know that enforcement is difficult and because they feel that even a court order may result in increased sales by them of other articles when the public is advised that they have been enjoined from selling a product below the price fixed by a manufacturer. The sympathy of the public often results in a greater volume of sales.

Everyone has the urge to buy goods as cheaply as possible. However, as President McKinley once put it: ${ }^{14}$

I do not prize the word cheap. It is not a word of hope; it is not a word of comfort; it is not a word of cheer; it is not a word of inspiration! It is the badge of poverty; it is the signal of distress; ... [C] ] heap merchandise means cheap men, and cheap men mean a cheap country.

In the price-cutting wars of the 1930 's, we had become a "cheap" country, with a vengeance. However, before long, it was realized that preserving the corner drugstore was more important than saving a few pennies on a tube of toothpaste. Today, the displacement of the small independent businessman presents a grave danger to our economy-and to our society. America should be under no illusions about the value or effect of promiscuous price-cutting. It has, indeed, been a potent weapon of monopoly - a means of killing the small rival.

\footnotetext{
${ }^{14}$ Campaign speech delivered at Cleveland, Ohio, Oct. 5, 1889, entitled Protection and Revenue, in SPEECHES AND AdDREsSes OF WilliaM McKinLey 368,376 (1894).
} 
II

\section{RetaILERs' Remedies}

After this review of the basic philosophy of the fair trade statutes, let us now turn to a consideration of the possible avenues of relief for the conventional retailers who distribute fair-traded merchandise.

First, it should be clear that if a retailer is doing business in a state which does not have a fair trade statute, he cannot, under ordinary circumstances, be heard to complain that he is being hurt by the price-cutting tactics of his competitor. However, if he finds that his competitor is selling a product either below or only slightly higher than the price at which he is able to buy it from the same manufacturer or producer, it would pay him to query whether his competitor is being favored by a special price from the manufacturer in violation of existing state law and possibly in contravention of the Clayton Act, as amended by the Robinson-Patman Act. Further, even if the manufacturer is not engaging in a discriminatory pricing practice, it may develop that the retail competitor who is cutting prices is "selling below cost" in violation of laws in effect in many of our states. Where interstate commerce is involved, it is also unlawful to sell goods at unreasonably low prices for the purpose of destroying competition or eliminating a competitor. ${ }^{15}$

Second, even in a state which does have a fair trade statute, if the particular commodity involved has not been fair-traded by the manufacturer, then, under ordinary circumstances, a retailer cannot complain of the price-cutting tactics of his competitor. This statement is, of course, subject to the same qualifications as indicated above concerning possible violations of other state and federal statutes.

But the problem facing most retailers today is not one existing in non-fair trade states and not one pertaining to non-fair-traded items. The problem has to do with price-cutting on items which have been fair-traded in states which have fair trade statutes. What can the conventional retailers do to protect themselves against the inroads being made by the discount houses? Should the conventional retailers "throw in the towel" and imitate the example of the discount houses? Or should they seek to compel adherence to the letter and spirit of our fair trade statutes?

Many manufacturers enter into fair trade agreements with their distributors and then do a fairly conscientious job of policing such fair trade agreements. However, there are some who fair-trade their products and then seek to maintain a "doubledealing standard" by compelling small retail outlets to adhere to the fair trade prices, while at the same time closing their eyes to the open and notorious price-cutting of the discount houses which handle a large volume of goods and which are in competition with the small independent retailers.

As a general principle, the less government intervention in business, the better. However, under certain circumstances, the government has not only a right, but also a duty to supervise the conduct of business in the public interest. Government

${ }^{16} 49$ STAT. 1528 (1936), I5 U.S.C. \$ 13a (1952). 
should come into the picture only to assure that the rules of the game are fair and that they are enforced in a way that will enhance our economic productivity.

Section $5(\mathrm{a})(\mathrm{I})$ of the Federal Trade Commission Act provides very generally that: 10

Unfair methods of competition in commerce, and unfair or deceptive acts or practices in commerce, are hereby declared unlawful.

But what are unfair methods of competition? What are unfair acts or practices? What are deceptive acts or practices? These are very important questions which the Federal Trade Commission has, for many years, been answering. The basic law itself is not definitive; and it probably was not made definitive because Congress could not possibly have enumerated all of the unfair methods of competition and all of the unfair or deceptive acts or practices capable of being engaged in by businessmen. Consequently, from time to time, the Federal Trade Commission is called upon to determine whether a new method of competition or a new act or practice is violative of the statute because it is unfair.

Given a set of circumstances wherein a manufacturer picks and chooses those against whom he will seek enforcement of the minimum resale price provision, is there any legislative authority for the FTC to intervene and enjoin such discriminatory practice? In my opinon, there is. The Commission, for about forty years now, has been attempting to ban unfair methods of competition in commerce. Since $193^{8}$, the Commission has also sought to ban unfair or deceptive acts or practices in commerce. The Clayton Act, as amended by the Robinson-Patman Act, prohibits certain specified discriminatory practices in commerce. The theory of all of these laws has been that competitors should start their race at the same starting point. If this is correct, is it fair for a manufacturer to compel one distributor to abide by a minimum resale price provision in a fair trade agreement, and at the same time sell to a competitor of such distributor (let us call that competitor a discount house) and not require the competitor to respect the minimum resale price fixed by the manufacturer?

Some might ask: "If the Federal Trade Commission should take such action, would it not in effect be seeking enforcement of the fair trade agreements?" The answer is "No." The Commission would not be seeking to enforce any agreement. It would only be seeking equal treatment of all distributors of the same manufacturer. It is submitted that the FTC has full authority to enjoin a manufacturer from discriminating in this manner. In compliance with an order of the Commission, the manufacturer would have the choice of doing one of two things: He would subsequently either have to enforce his minimum resale price provision against all distributors; or he would have to abandon all fair trade agreements. The choice would be up to the manufacturer; the Federal Trade Commission would not order him either to enforce or not to enforce the provisions of fair trade agreements. All that the Commission could order him to do would be to treat all distributors alike.

${ }^{10} 66$ STAT. 632 , I5 U.S.C. $\$ 45(a)$ (I) (I952). 
If this step were taken by the Federal Trade Commission, could it be accused of going beyond congressional intent? That any such criticism would be unjustified seems clear from a perusal of some of the provisions of the Clayton Act, as amended by the Robinson-Patman Act. Section 2(d) of the Clayton Act makes it unlawful for any person engaged in commerce to pay a customer for services or facilities unless such payment is available to all competing customers on proportionally equal terms. ${ }^{17}$ Section 2(e) prohibits the furnishing to one purchaser of services or facilities not accorded to all others on proportionally equal terms. ${ }^{18}$

- Obviously, the congressional intent was that customers be treated either equally or on proportionately equal terms. However, where a seller in interstate commerce offers a purchaser a contract with ten restrictive provisions, and at the same time offers to a competitor of such customer a contract with only nine restrictive provisions, it appears that the latter may receive a competitive advantage over the former and that this, in turn, may substantially lessen competition or tend to create a monopoly. (For purposes of the example, the tenth restrictive provision might be one pertaining to the maintenance of minimum resale prices.)

Let me not be misunderstood as stating that the discriminatory enforcement of the minimum resale price provisions of a fair trade agreement violates the Clayton Act, as amended by the Robinson-Patman Act. If there is a violation of law-and it is submitted that there is-then the violation is of section 5(a)(I) of the Federal Trade Commission Act.

Another matter of importance in connection with this problem concerns the rather widespread impression that the Sherman Act is violated if two or more retailers, or two or more wholesalers, combine to enforce compliance with a legal fair trade agreement. It is submitted that two or more individuals, whether or not competitors on the same business level, may combine when they seek only the enforcement of a legal contract. Very often, small retailers are not financially able to undertake the expense involved in bringing one or more suits against competitors who violate fair trade agreements. If two or more retailers may not combine and share legal expenses, it may mean that their businesses will be ruined and the discount house or discount houses in the area will subsequently enjoy a monopoly in the area for the distribution of the particular merchandise involved.

There is no question that responsibility for fair trade enforcement lies primarily with the manufacturers. Nevertheless, the fair trade laws generally provide that any injured party may undertake enforcement; and frequently, a retailer is in a better position to obtain fair trade enforcement than the manufacturer himself, since a retailer can seek an injunction against price-cutting on all fair-traded items offered for sale by him and by the discount house, but a manufacturer's complaint would necessarily have to be restricted to his own fair-traded products.

${ }^{17} 49$ STAт. 1526 (1936), 15 U.S.C. $\S \mathrm{r}_{3}(\mathrm{~d})$ (1952).

${ }^{18}{ }_{\text {Id. }} \S \mathrm{I}_{3}(\mathrm{e})$. 
If two or more injured retailers may combine in a suit to enforce one or more fair trade contracts, it seems logical to conclude that a manufacturer may combine with one or more of his retailers for the same purpose. With retailers filing the suits and with the manufacturers defraying the costs, a system of fair trade enforcement of maximum efficiency and of maximum economy would seem to have been discovered.

It is understood that small businesses have already been closed and bankruptcies have resulted because of the practices of discount houses. For their own self-preservation, retailers should solicit the assistance of the FTC when manufacturers discriminate in their enforcement of the minimum resale provision of fair trade agreements. Further, if retailers feel that they should protect their business by combining with their competitors only for the purpose of seeking compliance with fair trade agreements, and if the Department of Justice should advise them that such a combination may be deemed to violate the Sherman Act, then such businessmen should ask the Department to co-operate with them in bringing about a test case of this interpretation. In this same connection, it is interesting to note the statement of Federal Trade Commissioner Secrest at a recent Trade Practice Conference in Chicago:" "You can't be accused of collusion if you all get together to enforce the law. Now, if you get together to break it, you would be in collusion." Although Commissioner Secrest was referring to combinations of competitors to secure enforcement of Trade Practice Rules promulgated by the FTC, the principle seems applicable to combinations to enforce fair trade agreements.

In order to gain first-hand knowledge about fair trade, a subject of vital concern to small business, the Subcommittee on Retailing, Distribution, and Fair Trade Practices, of the Senate Select Committee on Small Business sought information from the manufacturers, distributors, and retailers who are actually practicing fair trade. During this survey conducted in mid-r956, when asked about the probable effect on their companies and industries if the Miller-Tydings and McGuire Acts were repealed, 23I firms felt that there would be substantial adverse effect upon their companies specifically and the industry as a whole. One manufacturer voiced apprehension over the status of small business, saying: ${ }^{20}$

We would consider that very serious effects would be encountered by our firm, as well as other small industries, should the Miller-Tydings Act and the McGuire Act be repealed. The reason for our concern is that big business with its unlimited capital and huge resources, could stand a program of narrow margins of profit should cutrate prices prevail in the wholesale and retail field, whereas small businesses would be seriously crippled and perhaps wiped out; in view of the present standard of inflation now prevailing in this country, and with the cost of doing business going up percentagewise a large group of small businesses would be wiped out should the two acts heretofore mentioned be repealed.

${ }^{10}$ FTC Transcript of Trade Practice Conference for the Work Glove Industry, Oct. I0, I958.

${ }^{20}$ Select Committee on Small Business of the Senate, Fair Trade, S. REP. No. 2819, 84 th Cong., $2 d$ Sess. II (1956). 


\section{THE FTC Position}

The Federal Trade Commission, on February 2I, I955, announced that it had denied an application for a Commission investigation into resale price agreement enforcement practices of certain unnamed manufacturers in the jewelry industry. In requesting action by the Commission, the applicants had charged that the manufacturers were using retail jewelers as a "show case stimulus to the business of discount houses" by forcing jewelers to hold to fair trade prices while allowing or encouraging discount houses to undercut fair trade prices.

In a letter to the applicants, the FTC rejected the theory that the applicants were engaged in unfair methods of competition in violation of the Federal Trade Commission Act. Because of its importance, the letter is quoted in full in a footnote. ${ }^{21}$

21 "Dear Sirs:

"Reference is made to your application to the Commission on behalf of — , in which you complain of alleged unlawful practices of certain unnamed manufacturers of watches, silverware, appliances, and related goods. You charge therein that these manufacturers discriminate between competing distributors of their product by deliberately selling fair-trade merchandise to so-called discount houses without requiring adherence to the fair trade prices, at the same time enforcing fair trade prices against retail jewelers. The purpose of such discrimination, it is alleged, is to establish the fair-traded retail jewelers as a 'show case stimulus to the business of discount houses.' The application charges that the disparate treatment of competing groups constitutes an unfair method of competition in violation of section 5 of the Federal Trade Commission Act. The Commission is requested to initiate an immediate investigation into the cited activities.

"The matter has been given intensive study by the Commission. For purposes of settling the legal issues involved, all factual allegations of the application, however controversial, have been construed in a light most favorable to the application.

"The Commission nevertheless decides, for the reasons set forth below, that the matter is not one in which Federal Trade Commission jurisdiction could be invoked.

"The authority of the Federal Trade Commission under fair trade is sharply circumscribed by the provisions of the McGuire Act. The Act does not impose on the Commission any affirmative regulatory duties; it does not in terms prohibit any practice nor require the Commission to take corrective action towards proseribed activities. The Act is exemptive and permissive. It specifies the conditions under which fair trade pricing and the rights of action created by State fair trade laws are exempt from the Federal antitrust laws.

"The Commission has consistently taken the position that it is not within the province of the Federal Trade Commission to exercise control over resale price agreements nor to enforce such agreements. Where resale price agreements are lawful under applicable State law, the Commission understands the McGuire Act as barring antitrust authorities from concerning themselves with the rights and obligations brought into existence by those agreements. Enforcement has been left exclusively to private litigation.

"The Commission agrees, however, that the withdrawal from the area of lawful fair trade should not be given too broad a connotation. It is fairly apparent that in varying competitive contexts-where the practice is not 'lawful,' or it is an integral part of a greater trade restraint-it may be attacked under the Federal antitrust laws. (Cf. United States v. Univis Lens, 316 U.S. 241 (1942); United States $v$. Bausch \& Lomb Optical Co., 321 U.S. 707 (I944); Eastman Kodak v. F.T.C., I58 F.2d 592 (I946).) But no contention is here made that the fair trade agreements entered into by these manufacturers are unlawful. The application apparently rests on the theory that the manufacturers utilize the device of fair trade to affect a larger competitive restraint-that is, an unlawful discrimination between competing channels of distribution in violation of section 5 of the Federal Trade Commission Act. The Commission cannot validate that theory.

"The application declares that remedies and corrective procedures made available at State Law, "have proved completely ineffective to remedy the wrong' and are 'not the answer to the problem.' 'These remedies inhere in the right afforded the manufacturer, competing retailers, and any person damaged by the willful and knowing action of sellers undercutting the fair trade price to bring an action in State court. The action may be either a damage suit, where the violator is a signatory to a fair trade 
With respect to the Commission's position that the McGuire Act does not impose upon the FTC any affirmative regulatory duties and does not in terms prohibit any practice or require the Commission to take affirmative action towards proscribed activities, it is important to examine the McGuire Act closely. The first section sets forth the purpose of the legislation, ${ }^{22}$ and the second amends section 5 (a) of the Federal Trade Commission Act by adding four new paragraphs, numbered 5 (a) (2) through 5(a)(5). Paragraphs 5(a)(I) and 5(a)(6) are not new, but they are included in the McGuire Act as part of the amended section $5(\mathrm{a})$ of the Federal Trade Commission Act.

contract, or a suit for injunctive relief which is available against signers and nonsigners alike. Assuming the truth of applicants' allegation that no relief against price cutters has been forthcoming from the manufacturers, it is still clear that applicants may resort to various avenues of self-help to correct the conditions of which they complain.

"In the first instance, fair-trading retailers may sue for injunctive relief against offending discount houses under the applicable State Acts. Relief would not be conditioned upon proof of the manufacturer's intent or of his complicity in the price cutting; proof need only be shown of the discounter's knowledge and willful disregard of the fair trade price.

"But beyond injunctive relief against competing discounters, retailers have a further broad area of self-help available: disregarding the resale prices fixed by the manufacturer and competing on a price basis with the discount houses. The decisions of State courts under the fair trade acts make it clear that where a manufacturer discriminates in the enforcement of his resale prices among competing customers, or fails to display reasonable diligence in enforcement, or neglects to enforce, that fact constitutes an adequate defense in a later enforcement proceeding by the manufacturer against a price-cutting seller. These decisions invoke the equity principle of 'unclean hands' against the manufacturer, or hold that he has 'waived' his rights under the contract, or 'abandoned' his rights under the State statute. Thus, a retailer forced to cut prices to compete, under conditions here alleged, could do so with impunity.

"The application has sought to anticipate this second self-help technique by declaring that a retailer is not himself required to violate a contract, law, or public policy to obtain equal footing with his favored competitor, citing in support of this contention Federal Trade Comm'n v. Keppel \& Bro., Inc., 291 U.S. 304,313 (1934), a lottery case, where it was stated:

'A method of competition which casts upon one's competitors the burden of the loss of business

unless they will descend to a practice which they are under a powerful moral compulsion not

to adopt, even though it is not criminal, was thought to involve the kind of unfairness at which

the statute was aimed.'

Inferentially, the status of retail jewelers is equated with that of the disfavored competitors in Keppel. But the present situation differs markedly from Keppel. As a matter of law, if a manufacturer has persisted in the course of conduct here alleged, he has forfeited his rights to enforcement and there is no longer any legal obligation-or at least any legally enforceable obligation-upon a retailer to continue to observe the manufacturer's fixed prices. In contrast to the lottery method of Keppel, it cannot seriously be suggested that price competition is morally reprehensible.

"The Federal Trade Commission must act in the public interest, to affirm, wherever possible, the basic competitive rationale of our free enterprise economic system. The Commission believes that the applicants here, through their own lawful efforts, may obtain the relief desired. In the absence of a showing that circumstances foreclose such efforts, the Commission cannot invoke antitrust sanctions in support of aggrieved applicants reluctant to effect that measure of self-help which would alleviate their condition.

"No ground is cited which affords a present basis for a proceeding under section 5 of the Federal Trade Commission Act.

"The application for an investigation has been denied.

"By direction of the Commission.

\section{Robert M. Parrish Secretary."}

Federal Trade Comm'n Press Release, Feb. 2I, r955.

${ }^{22} 66$ STAT. 63x, I5 U.S.C. $\$ 45$ note (1952). The amended statute, as contained in the Code, does not set forth the purpose of the McGuire Act amendment to the Federal Trade Commission Act. Such purpose, as enacted by Congress, is set forth in the footnote, entitled "Purpose of Act July I4, 1952." 
Even if the new sections do not impose any affirmative regulatory duties upon the Commission or in terms prohibit any practice, why would the Commission expect Congress to include in these new sections language which was already in the two old sections-language reaffirmed by Congress when it passed the McGuire Act. Section $5\left(\right.$ a) (I) reads: $:^{23}$

Unfair methods of competition in commerce, and unfair or deceptive acts or practices in commerce, are hereby declared unlawful.

Section 5 (a) (6), with inapplicable deletions, states: ${ }^{24}$

The Commission is hereby empowered and directed to prevent persons, partnerships, or corporations . . . from using unfair methods of competition in commerce and unfair or deceptive acts or practices in commerce.

While the four new sections in the McGuire Act do not, when taken alone, impose upon the Commission any affirmative regulatory duties, and while they do not in terms prohibit any practice or require the Commission to take corrective action towards proscribed activities, how can the Commission ignore the provisions of sections $5(\mathrm{a})(\mathrm{r})$ and $5(\mathrm{a})(6)$ which have been part of the Federal Trade Commission Act for many years? Section 5 (a)(6) not only empowers the Commission to take certain action, it actually directs the Commission to do so. Congress could not have made its intention any plainer!

The four new sections added to section 5(a) of the Federal Trade Commission Act by the McGuire Act merely provide that certain contracts or agreements illegal before the enactment of the McGuire Act were cleansed of such illegality by the passage of the McGuire Act. However, there is nothing in the McGuire Act which exempts practices, as distinguished from contracts or agreements, from the provisions of the Federal Trade Commission Act or of the antitrust laws. Consequently, if a practice was illegal prior to the enactment of the McGuire Act, it is still illegal now, because the McGuire Act exempts only the certain contracts or agreements described therein.

Th FTC emphasizes that it has consistently taken the position that it is not within its province to exercise control over, or to enforce, resale price agreements. Obviously, Congress never intended for the Commission to undertake such enforcement. However, if the FTC should take action with a view to enjoining a manufacturer from continuing the practice of enforcing minimum resale provisions of a fair trade agreement against only some of his distributors, would the Commission be enforcing fair trade agreements? Of course not! Instead, the FTC would only be seeking equal treatment of all distributors by the same manufacturer.

Paragraph six of the Commission's letter remarks:

It is fairly apparent that in varying competitive contexts-where the practice is not "lawful," or it is an integral part of a greater trade restraint-it may be attacked under the Federal antitrust laws. (Emphasis added.)

${ }^{23} 66$ StAT. 632, 15 U.S.C. $\$ 45(a)(1)$ (1952). $\quad{ }^{24} I d . \$ 45(a)(6)$. 
However, in the next sentence the Commission adds:

But no contention is here made that the Fair Trade agreements entered into by these manufacturers are uniawful. (Emphasis added.)

Thus, a nimble transition is made from "practices" to "agreements."

Why should "agreements" and their legality be involved in the first place? The jeweler-petitioners were complaining to the Commission about the practice of some manufacturers who discriminate among competing retailers by deliberately selling fair-traded merchandise to the discount houses without requiring adherence to the fair trade prices and at the same time enforcing those prices against other retail jewelers. If the practice is not lawful, it should make no difference whether the agreement involved is a fair trade agreement or any other kind of agreement; and, likewise, it should make no difference whether the underlying agreement is lawful or unlawful.

In its letter, the FTC seems to indicate, though it never expressly so states, that complaining retailers who seek to abide by fair trade agreements should first exhaust all other remedies open to such retailers before they come to the Commission for assistance. While it is true that the complaining retailers do have the right to resort to other avenues of relief, it is not required by any statute that they exhaust such avenues before presenting their problem to the FTC. Section $5(\mathrm{~b})$ of the Federal Trade Commission Act provides, in part: ${ }^{25}$

Whenever the Commission shall have reason to believe that any such person ... has been or is using any unfair method of competition or unfair or deceptive act in commerce, and if it shall appear to the Commission that a proceeding by it in respect thereof would be to the interest of the public, it shall issue and serve upon such person . . . a complaint stating its charges. ... .

Thus, the only two statutory prerequisites for FTC action are: (I) the Commission must have reason to believe that a particular person has been, or is, using an unfair practice in commerce; and (2) the Commission must believe that a proceeding by it in respect thereto would be in the public interest. Clearly there is no requirement in the statute that the Commission find that no avenues of self-help are available to the complaining party.

The ninth paragraph of the Commission's letter is especially surprising. There, in effect, the Commission recommends that a distributor violate and ignore the provisions of a valid agreement entered into between himself and the manufacturer. This reasoning that "two wrongs make a right" might involve the retailer who adopted it in some very unfortunate litigation. It is, indeed, extraordinary for the FTC to tender legal advice on a matter that is so controversial and is not covered by any of the laws which the Commission administers.

In the eleventh paragraph of its letter, the Commission emphasizes that it "cannot invoke antitrust sanctions in support of aggrieved applicants reluctant to effect that

${ }^{25}{ }_{52}$ STAT. III (1938), 52 STAT. 1028 (1938), I5 U.S.C. $\$ 45(b)$ (1952). 
measure of self-help which would alleviate their condition." It has already been noted in this paper that Congress certainly never evidenced any intention to require an exhaustion of remedies. The Clayton Act, as amended by the Robinson-Patman Act, is also an antitrust statute and is also administered by the FTC. Section eleven of that Act provides: ${ }^{26}$

Whenever the Commission ... shall have reason to believe that any person is violating or has violated any of the provisions of sections two, three, seven and eight of this Act, it shall issue and serve upon such person ... a complaint stating its charges in that respect. ...

Under that Act, the Commission does not even have to hold that a proceeding in respect thereof would be in the public interest. Where then does the FTC find authority for its view that "antitrust sanctions" can only be invoked in favor of those applicants who have already utilized all available self-help?

\section{ConcLusion}

In a recent public address, Senator Hubert $\mathrm{H}$. Humphrey, a leading protagonist for small business in the United States, commented that "there has been considerable evidence in recent years that our business climate contains many elements hostile to the well-being of the average independently-owned and operated small business concerns."27 The small businesses are fighting hard for survival, and it behooves the federal government to render whatever statutory assistance is possible and consistent with the public interest.

Senator Humphrey also said: "At the present time, the retailer exists in what has been described as an atmosphere of catastrophe." He referred to a statement made by Mr. Victor Lebow, a marketing consultant, who had testified before the Senator's subcommittee during its study of discount house operations. Mr. Lebow told the subcommittee that a retail store opening today has only a seventy-four per cent chance of surviving beyond its first half year of existence; it has a forty-nine per cent chance of living $2 \frac{1}{2}$ years; and only seventeen per cent will still be in existence ten years from now.

Obviously, many causes exist for the small businessman's plight-among them: (I) discriminatory pricing practices; (2) combinations and agreements among the larger firms; (3) mergers and consolidations that accentuate the trend towards "bigness"; (4) tax inequities which work to the disadvantage of the smaller businesses; and (5) lack of adequate sources of capital at reasonable interest rates. However, the existence of many other problems for the small businessman does not excuse failure to take steps to stamp out the discrimination in fair trade practices which has been the subject of this paper.

\footnotetext{
${ }^{20} 64$ STAT. II25 (1950), I5 U.S.C. $\$ 2$ (1952).

${ }^{27}$ From an address by Senator Hubert $H$. Humphrey before a convention of the National Association of Retail Druggists, Oct. 2, 1958.
} 